\title{
Nytt medisinrom ga færre feil
}

\author{
Endring av rutiner for medisinhåndtering ved sykehjemmet, \\ som å flytte medisinrommet, reduserte avvik.
}

D ette prosjektet viser at gode arbeidsforhold og enkle tiltak kan redusere feil i legemiddelhåndtering i sykehjem. Nytt medisinrom og magnetplater reduserer avvik i forbindelse med medikamenthåndteringen. Ansatte i dette prosjektet hadde over tid meldt inn avvik, som at medikamenter ikke var lagt i dosett, og at feil tablett var lagt i dosett. Dette var også tema da en sykepleierstudent i praksis skulle se kritisk på hvorvidt de sykepleiefaglige rutinene i avdelingen var i samsvar med kunnskapsbasert praksis, og komme med forslag til hvordan rutinene eventuelt kunne forbedres. Hun viste til avviksmeldinger om feil ved og manglende medikamenter i dosettene, forstyrrelser under opplegging av medikamenter, og medisiner som ble satt på nattbordet da pasienten sov på medisinrunden. På bakgrunn av disse avviksmeldingene ble det nedsatt en prosjektgruppe. Hensikten med prosjektet var å redusere feil i legemiddelhåndteringen i avdelingen.

\section{Hovedbudskap}

Ved hjelp av samarbeid og faglige argumenter kan man endre rutiner, som igjen kan bedre pasientens sikkerhet.

\section{Søkeord}

Les mer og finn litteraturhenvisninger på våre nettsider. \ Legemidler | Kvalitet | Arbeidsmiljø | Sykehjem

\section{Krevende oppgave}

Sykepleiere håndterer hundrevis av medisiner hver dag til mange pasienter med en rekke ulike sykdommer. Medikamenthåndtering er en krevende oppgave som krever kunnskap og nøyaktighet for å utføres korrekt. Undersøkelser viser til feil i dosering, administrering, legemiddel og at legemiddel blir gitt til feil pasient $(1,2)$. Eksempler på årsaker til feilene var handling ut fra "gammel refleks», rutinene ble ikke fulgt, manglende ferdigheter eller slurv, samt manglende kompetanse og dårlige rutiner. Slike feil kan medføre at pasienten ikke får det rekvirerte legemidlet, noe som får konsekvenser for behandlingen. 79 prosent av 775 sykepleiere i en amerikansk undersøkelse forteller at de fleste feil i medikamenthåndtering skjer når de blir avbrutt under medisinoppleggingen, når bemanningen er lav, når det er mange pasienter per sykepleier, uleselige medisinkort, feil i medikamentregningen og forveksling av medikamenter som har likt navn eller lik emballasje. (3). Undersøkelser viser også at utydelige eller ufullstendige skrevne ordinasjoner er en betydelig årsak til feil ved istandgjøring av legemidler (4-9). Leap (6) gjorde allerede i 1995 en systemanalyse av uheldige hendelser med legemidler. Den viste at doseringsfeil forekom hyppigst (28 prosent). Av disse feilene var 50 prosent feil på bakgrunn av legens håndskrevne kurver.

\section{Prosjektet}

Prosjektgruppen besto av avdelingsleder, en sykepleier, en hjelpepleier, sykehjemslege, veileder fra høyskolen og de sykepleierstudentene som til enhver tid var i avdelingen. Førsteforfatter ledet prosjektet, og prosjektperioden ble satt til ett år. Prosjektgruppen hadde møter med personalet for å enes om hvilke tiltak avdelingen skulle igangsette og hadde møter med virksomhetsleder der det var nødvendig. På personalmøtet presenterte prosjektgruppen studentens oppgave, og personalet erkjente at arbeidsforholdene og rutinene rundt legemiddelhåndtering ikke var gode nok. Personalet ble enige om at dette ville de gjøre noe med. Forskningsspørsmålet ble: Hvordan redusere feil i legemiddelhåndteringen i avdelingen? Personalet ble enige om å undersøke to områder: arbeidsforholdene på medisinrommet og rutiner for legemiddelhåndtering.

\section{Arbeidsforhold}

For å kartlegge forstyrrelsene under medisinoppleggingen ble det laget en registreringsliste der man førte opp hver gang det fysisk kom noen inn på rommet og avbrøt den ansatte under ilegging av medikamenter i dosett. Her ble det registrerte antall ganger sykepleierne ble forstyrret under dosettileggingen. I løpet av en uke ble det lagt medikamenter i dosett tre ganger, hver gang tok det cirka 1,25 time. I løpet av uken ble det registrert ti forstyrrelser under dosettilegging. Det vil si litt mer enn tre forstyrrelser i løpet av én time og 25 minutter. Dette viser bare de faktiske forstyrrelsene som var under selve medisinoppleggingen. Hvis alle forstyrrelsene, som telefonanrop på vaktrommet, snakk utenfor medisinrommet og støy fra dagligstuen var tatt med, ville antall forstyrrelser blitt hyppigere. En undersøkelse gjort i sykehus viser at sykepleieren ble 
(9) Prosiektarbeid

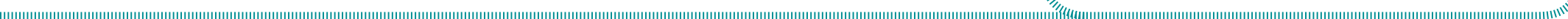

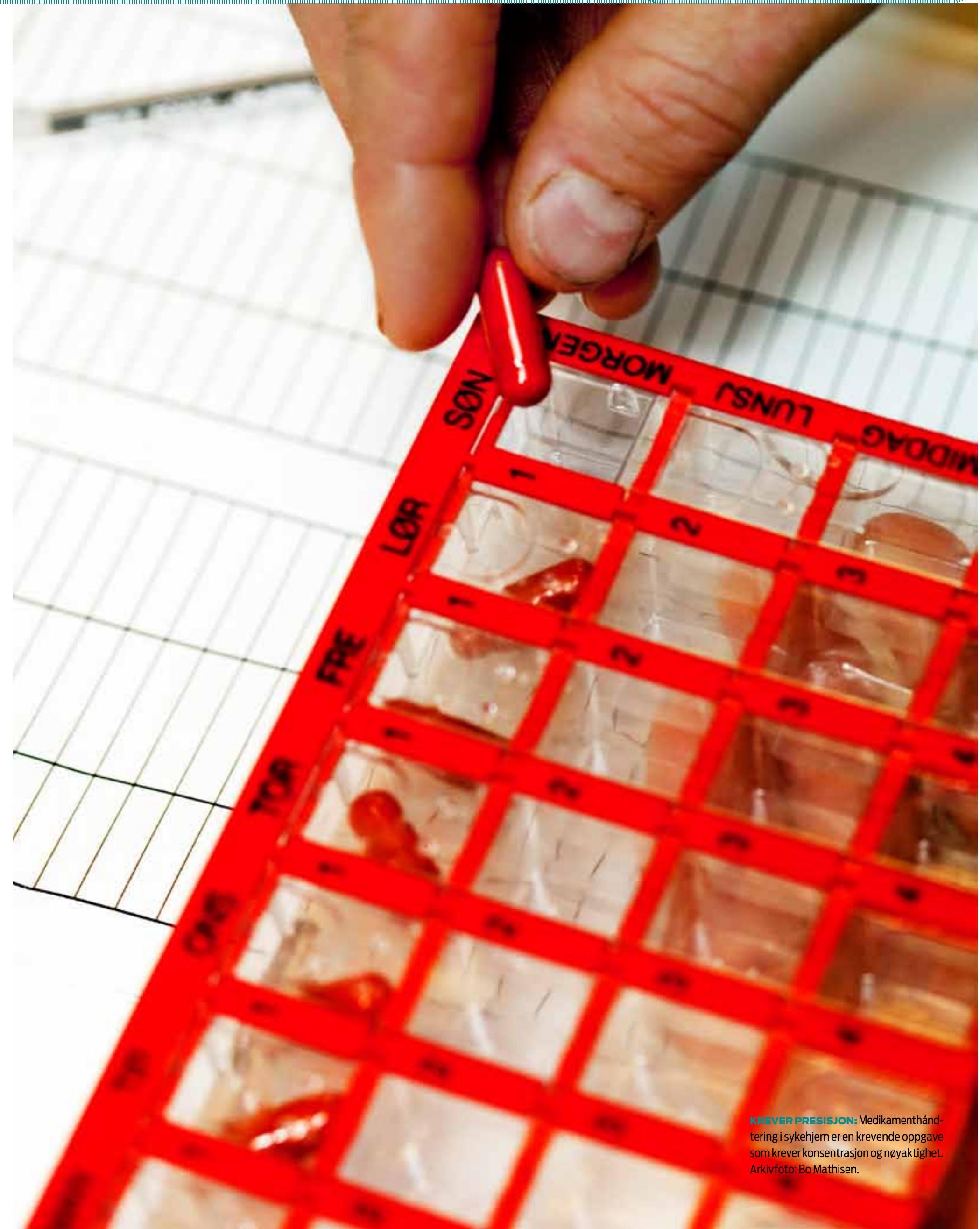


avbrutt fra hvert annet til hvert tredje minutt (10). En stadig avbrytelse i arbeidet skaper uro, og sykepleierne kan miste konsentrasjonen, noe som kan medføre feil (11).

\section{Tiltak}

Som et forsøk på å redusere forstyrrelser ved ilegging i dosetter ble det satt opp et skjermbrett med en plakat der det sto «ikke forstyrr». Skjermbrettet ble satt opp som en fysisk hindring foran medisinrommet. Dette resulterte i færre forstyrrelser, men fungerte likevel ikke

\section{«I løpet av uken ble det re- gistrert ti forstyrrelser under dosettilegging.»}

optimalt. Dette tiltaket ble også forsøkt ved flere amerikanske sykehus i tidsrommet 2006-2009 (12). Sykepleierne hadde testet ulike tiltak, som refleksvester med teksten «ikke forstyrr» på ryggen, «stille soner», og ekstra oppmerksomhet om konsentrasjon de tidspunktene arbeidet foregikk på. Disse forslagene viste seg å redusere feilprosenten betydelig. Selv om skjermbrettet ble satt opp, var det fortsatt forstyrrende støy fra telefoner og aktiviteter i dagligstua, og mange opplevde stress og uro under dosettileggingen. Hverdagen i en somatisk sykehjemsavdeling er hektisk, med pasientalarmer som ringer og mye trafikk i korridorene. Sykepleierne făr ofte en følelse av at de måtte skynde seg for å bli ferdig med dosettene, slik at de kan ta del i arbeidet utenfor. Andre studier viser også at tidspress, der mye skal skje på samme tid, kan føre til feil (11).

\section{Forstyrrelser}

For ytterligere å redusere forstyrrelsene ble det sett på hvor medisinrommet var plassert og hvordan det var utformet. Medisinrommet var plassert midt i bygget. Her var det mye trafikk både fra pårørende, beboere og personell. Avdelingsleders kontor var rett overfor medisinrommet, og telefoner til avdelingen var et av de forstyrrende elementene. Mange følte de var nødt til å svare på telefoner som ringte selv om de sto og la opp medisin. Det var også enkelt for personalet, beboerne og pårørende å stikke hodet inn til den som sto og la opp medisiner for å få et kjapt svar på spørsmål. I tillegg var det mye uro og støy fra ulike aktiviteter i fellesstuen, ikke langt unna medisinrommet. På avdelingen kunne sykepleierne lukke døren, men medisinrommet var et lite rom med dårlig ventilasjon og trange arbeidsforhold. Sykepleierne ble fort slitne og ukonsentrerte på grunn av dårlig luft. Mange følte det også klaustrofobisk å stå lenge inne i et så lite rom. Hågensen (4) har undersøkt arbeidsforholdene på medisinrom. Hennes informanter uttrykte at rommene fysisk sett var små, eller de var dårlig utformet i tillegg til å ha dårlig ventilasjon. Chaudhurys (13) studie viser hvilken betydning utforming av sykepleierens arbeidsrom har for effektivitet og sikkerhet, når de skal håndtere legemidler. Utformingen har betydning for å redusere sykepleierens trøtthet og risikoen for å gjøre feil. I et optimalt utformet medisinrom var godt lys, lyse farger, god ventilasjon og lite støy ansett som viktig. Å lukke døren var derfor ingen løsning.

\section{Nytt medisinrom}

På bakgrunn av undersøkelsene og erfaringene som ble gjort, foreslo prosjektgruppa å flytte medisinrommet til et annet sted i bygget, hvor det var mindre trafikk og man slapp forstyrrelser fra telefoner og andre aktiviteter på avdelingen. Dette ville bidra til mer ro rundt medisinopplegget. De som skulle legge opp medisiner ville kunne trekke seg tilbake og konsentrere seg fullt om den oppgaven de skulle gjøre. Det nye medisinrommet var større og hadde mye bedre ventilasjon. Rommet ble malt i en lys farge og fikk en lys benkeplate. Sykepleierne kunne lukke døren og få den roen under medisinopplegg som de trenger. Etter at medisinrommet var blitt flyttet, ble det umiddelbart registrert nedgang $\mathrm{i}$ avvik knyttet til feil lagt i dosettene, og i ettertid er det meldt inn få avvik om dette problemet. De ansatte blir ikke like trette og uopplagte, og det er lettere å holde orden. Hvis noen trenger å ta ut medisiner mens medisinopplegg foregår, banker de enten på døra eller går stille og rolig inn og henter det de skal ha uten å forstyrre. Det er tre avdelinger på sykehjemmet, og samtlige avdelinger har flyttet sine medisinrom.

\section{Medisinene på nattbordet}

Et annet avvik som var registrert, var at sykepleier satt medikamentene i et glass på nattbordet dersom pasienten sov da de gikk runde. Denne kilden til feil er presentert i flere undersøkelser, som viser at medikamenter enten settes på nattbordet eller i nattbordsskuffen (4,11). For eksempel kan andre pasienter ta medikamentet, eller en pleier som ikke har kontrollert at det er riktig medikament til riktig pasient, kan gi medikamentet i forbindelse med måltid. Dersom pasienten sov, hendte det at pasienten ikke fikk morgenmedisin før ut på formiddagen, og med det ble tidspunktene mellom ulike medikamenter forskjøvet. I en studie ved 36 helseinstitusjoner i USA vises det til at 19 prosent av feil i medikamenthåndteringen var knyttet til at det ikke var rett pasient, riktig medikament, riktig dose, riktig tid eller riktig måte (14). I tillegg er ikke medikamentet gitt før pasienten har tatt det. Som hjelp til å registrere hvem som ikke hadde fătt morgenmedisin, og fjerne rutinen med å sette medisin på nattbordet, ble det laget en liten magnetplate som ble satt opp utenfor døren hos pasienten. Dersom en pasient sover eller skal hjelpes med måltidet, setter man opp en blå eller rød knapp med pasientens romnummer på magnetplaten. Blå eller rød fordi avdelingen er delt i en rød og en blå side. Slik kan den som skal inn til pasienten med måltidet se at pasienten ikke har fått medisin og hente den som har ansvar for å dele ut medisinen, eller gi den selv. En positiv bieffekt er at personalet ser hvem som ikke har fått frokost og morgenmedisin når de går i korridoren. III!

Prosjektet ble gjennomført med samarbeidsmidler fra Høgskolen i Bodø, nå Universitetet $i$ Nordland.

\section{LITTERATUR}

Teigen I Rendum K, Slørdal L, Spigset O. Feilmedisinering hos pasienter innlagt i sykehus. Tidsskrift for Den norske legeforening. 2009; 129:1337-41. Legemiddelhåndtering for virksomheter og helsepersonell som yter helsehjelp. Oslo: Helsedirektoratet; 2008.

3. Jones JERN, Treiber LPRN. When the 5 Rights Go Wrong: Medication Errors From the Nursing Perspective. Journal of Nursing Care Quality. 2010; 25(3): 240 .

4. Hågensen G. «Pasientens sikkerhet - sykepleierens ansvar?»: et bidrag for å synliggjøre opplevelsen av ansvarsforhold ved legemiddelhåndtering. 2010.

5. Settemsdal EM. Ansvarsutvikling: en pådriver for et forsvarlig system: en studie om legemiddelhăndtering og feil og avvik med medisiner blant kliniske sykepleiere på sykehus. Trondheim: E.M. Settemsdal; 2008.

6. Leape LL, Bates DW, Cullen DJ, Cooper J, Systems analysis of adverse drug events. Jama. 1995; 274(1): 35.

Storli M. Feilmedisinering i sykehus - organisasjonskulturens påvirkning. Vård i Norden. 2008 (Årg. 28, nr. 3 = Nr. 89): 19-23.

8. Elizabeth H.Winslow, Vanessa A Nestor Shirley K Davidoff Pamela G. Than Thompson, Jimite . Boric (2004) Legbity a completenss of phyand Critical CareVolume 26. Issue 2, March-April 1997. Pages 150-164).

C. potensiell kilde til feilmedisinering. Tidsskrift-Norske Legeforening. 2004: 124:2259-60.

10. Friberg, A. Vad kan vi lära oss av våra misstag? Sjukhusfarmasi 1993; nr. 1: 24-30.

11. Måløy E. Ansvarsutvikling: en pådriver for et forsvarlig system: en studie om legemiddelhåndtering og feil og avvik med medisiner blant kliniskesykepleiere på sykehus. Trondheim: Institutt for sosialt arbeid og helsevitenskap, NTNU; 2009.

12. Colliver V. Prescription for success: Don t bother nurses. San Francisco2009; Available from: http://articles.sfgate.com/2009-10-28/news/17185347_ medication-errors-integrated-nurse-leadership-program-ucsf-program.

13. Chaudhury H, Mahmood A, Valente M. The Effect of Environmental Design on Reducing Nursing Errors and Increasing Efficiency in Acute Care Settings: A Review and Malysis of the Literature. Environment and Behavior 2009; 41(6): 755 .

14. Westbrook J, Woods A, Rob M, Dunsmuir W, Day R. Association of interruptions with an increased risk and severity of medication administration errors. Archives of internal medicine. 2010; 170(8): 683.

Fagartikler kan sendes til torhild.apall@sykepleien.no 